\title{
Polysaccharide films modified by compounds of natural origin and silver having potential medical applications
}

\author{
Adrian Krzysztof Antosik (1) - Piotr Miądlicki (1) Katarzyna Wilpiszewska (1) - \\ Agata Markowska-Szczupak (1) - Zvi C. Koren (1) - Agnieszka Wróblewska (1)
}

Received: 10 January 2021 / Accepted: 5 June 2021/Published online: 17 June 2021

(C) The Author(s) 2021

\begin{abstract}
In the first stage, seven polysaccharide films were prepared with varying compositions of starch, carboxymethyl starch (CMS), and carboxymethyl cellulose (CMC), together with glycerol and citric acid. From these samples, the most suitable film for possible future applications in medicine in the form of patches was selected based on tensile strength tests, solubility in water, moisture sorption, swelling, and wetting angle. This film (labelled as "V") contained (in wt\%) CMS (2.5), CMC (2.5), citric acid (3), and glycerol (3). In the second stage, the selected film was used for further applications by individually introducing into it appropriate additives with known antimicrobial activity.
\end{abstract}

\section{A. K. Antosik · K. Wilpiszewska}

Faculty of Chemical Technology and Engineering,

Department of Chemical Organic Technology and

Polymer Materials, West Pomeranian University of

Technology Szczecin, Pułaskiego 10, 70-322 Szczecin,

Poland

e-mail: adriankrzysztofantosik@gmail.com

K. Wilpiszewska

e-mail: Katarzyna.Wilpiszewska@zut.edu.pl

P. Miądlicki · A. Wróblewska ( $\square)$

Faculty of Chemical Technology and Engineering,

Department of Catalytic and Sorbent Materials

Engineering, West Pomeranian University of Technology

Szczecin, Pułaskiego 10, 70-322 Szczecin,

PL, Poland

e-mail: Agnieszka.Wroblewska@zut.edu.pl
These additives consisted of terpene compounds of natural origin ( $\alpha$-pinene, menthol, and eugenol) as well as colloidal silver. These four films were then studied to determine the influence of the appropriate additive on moisture absorption, solubility in water, swelling, and antimicrobial activity. The results of the microbiological tests confirmed the antimicrobial activities, and also the anti-infective and regenerative effect of these films. In general, the films containing terpenes showed comparable or better medicinal properties than the film obtained with colloidal silver. A patch prototype (with a medical net) based on the optimal film ("V") was developed, and its flexibility is apparent in that it can take the shape and size of the area on the human body that it should cover.

\section{P. Miądlicki \\ e-mail: Piotr.Miadlicki@zut.edu.pl}
A. Markowska-Szczupak
Faculty of Chemical Technology and Engineering,
Department of Chemical and Process Engineering, West
Pomeranian University of Technology Szczecin, Piastów
42, 71-065 Szczecin, PL, Poland
e-mail: agata.markowska@zut.edu.pl

\section{Z. C. Koren}
Shenkar College of Engineering, Design and Art, Department of Chemical Engineering, The Edelstein Center, 12 Anna Frank St, 52526 Ramat Gan, Israel e-mail: zvi@shenkar.ac.il 


\section{Graphical Abstract}



Keywords Polysaccharides · Films · Patches · Silver $\cdot \alpha$-Pinene $\cdot$ Menthol $\cdot$ Eugenol

\section{Introduction}

The use of natural substances in the treatment of skin diseases and wounds has been known for centuries. Examples of such natural compounds include honey, butter, milk, myrrh, and resin. Gauze with carbolic acid (phenol), invented by surgeon Joseph Lister (1860s), and wound dressings sterilized with dry heat, steam and pressure, implemented by Robert Wood Johnson (1890s), co-founder of the Johnson \& Johnson company, made the first steps in the development of patches. In the 1960s, the first generation of dressings appeared, which were polymer films made of polyethylene, polypropylene, or polyester. They were not permeable to moisture and caused an accumulation of body fluids on the surface of the wound, which delayed the healing process (Queen et al. 2004). Subsequently, the second generation of dressings made of pure polyurethane or carboxymethyl cellulose (CMC) and polyisobutylene (hydrocolloid dressings) appeared. However, they did not have a curative effect as their main disadvantage was that they adhered to the newly formed tissue, which could lead to its damage. The third, and latest, generation of dressing materials includes polyurethane films and hydrogels. The most advantageous feature of hydrogels is keeping the wound moist, which speeds up the healing process, allows for a painless change of the dressing, and prevents excessive loss of body fluids. The three-dimensional structure of the hydrogel supports the creation of a protective barrier against infection and traps the bacteria from the wound within the macromolecule. Such patches make it possible to absorb the exudate with the contamination, and, thus, the wound is constantly cleaned. In addition, the patch is an oxygen-permeable layer that facilitates cell regeneration and protects against the development of dangerous microbial growth (Petkow and GórkiewiczPetkow 2002; Bialik-Wạs and Pielichowski 2011; Wachal et al. 2018).

Polysaccharides are biopolymers and can be good alternatives to the conventional polymers obtained from the petrochemical industry. These materials meet the "principles of 5E": efficiency, energy saving, enabling, economy, and environmental friendliness. Films obtained on the basis of biopolymers are very often used in the production of containers, bags, and packages, but at the same time new applications are being sought for these materials (Liu et al. 2004; Tey et al. 2007). One of the ways of modifying this type of material is the incorporation of colloidal silver or compounds of natural origin (terpenes) into them, which extends their applications in medicine and agriculture due to the antibacterial and antifungal 
properties of this type of material (Spychaj et al. 2013a; Drewnowska et al. 2017; Hassan et al. 2018).

Starch is a polysaccharide compound that has been used to protect skin against moisture, to prevent abrasions, and to accelerate the regeneration of the epidermis. Potato flour has also found widespread use in the form of aqueous solutions (Hovgaard and Brondsted 1996; Lee et al. 2009). Baths in starch accelerate the reconstruction of damaged skin and help fight pricks and skin changes occurring, e.g., in acne or seborrheic dermatitis. In the case of hands and feet, the use of starch soothes the skin, speeds up the renewal of the epidermis, and inhibits excessive sweating (Gebelein et al. 1991; Alberta Araújo et al. 2004; Lautenschläger 2009). In addition, carboxymethyl cellulose has found applications in medicine, and, e.g., is used as an emulsion stabilizer for injections, an adhesion and film-forming agent in tablets, for the relief of burning and itching of eyes, and as a safe and reliable carrier of anticancer drugs (Guo et al. 1998; Kamel et al. 2008). The films prepared on the basis of carboxymethyl cellulose can also be effective in the control of wound infections (Wong and Ramli 2014).

Starch, carboxymethyl starch (CMS), and carboxymethyl cellulose (CMC) are green polymers with great importance in pharmaceuticals, medicine, cosmetics, environmental protection, and the food industry (Spychaj et al. 2013b; Basta et al. 2013). Additional examples of their usage include as thickening and sizing agents in the textile industry, personal care products, and in surfactant systems, as flocculants, drilling fluids, and coating materials (El-Saied et al. 1994; Liu et al. 2008; Zdanowicz and Spychaj 2014).

The use of biopolymers from different sources has been investigated for many years for pharmaceutical and biomedical applications. Polymers such as alginate, chitin, chitosan, pectin, and gelatin are used as wound healing materials and their properties make them beneficial for use in wound dressings (South and Lyon 2010; Smith et al. 2016). The multifunctional behavior and tenability of biopolymers-from woven fibers that swell on contact with exudate, to water-rich hydrogels, which can encourage and maintain a moist wound environment in dry wounds-facilitate their application to a wide variety of wound types (South and Lyon 2010; Smith et al. 2016). Film properties are increasingly being designed to obtain physiological compatibility and the ability to control the release of drugs when exposed to various biological environments. This would lead to the development of smart, physiologically responsive biopolymers (Singh et al. 2017; Koneru et al. 2020).

Films obtained from polysaccharides, glycerol, and citric acid may also have medicinal properties similar to those of starch and carboxymethyl cellulose (Antosik et al. 2017; Antosik and Wilpiszewska 2018). Moreover, the incorporation of metals (e.g. gold, silver, and copper) or compounds of natural origin (such as, $\alpha$-pinene, menthol, and eugenol) to these films, may additionally increase the application potential of these types of materials in dermatology (Kaur et al. 2010; Bachiega et al. 2012; Kamatou et al. 2013). Both metal compounds and also $\alpha$-pinene, menthol, and eugenol have anti-inflammatory and bactericidal properties. The latter can also have a regenerating and moisturizing effect on the epidermis (Rufino et al. 2014; Ali et al. 2015; Midha et al. 2017; Lin et al. 2017). The use of the material obtained on the basis of carboxymethyl cellulose and with the addition of silver as a material with high microbiological activity that can be used to prepare wound dressings has been previously described (Hassabo et al. 2015; deBoer et al. 2015).

In consideration of the previously published literature data, the aim of our work was to first develop antimicrobial polysaccharide films consisting of various compositions of starch, CMS, and CMC, together with glycerol and citric acid. Following that, the most suitable of these films was chosen for further development based on tensile strength, solubility in water, moisture sorption, swelling, and wetting. This optimal film was then individually imbued with additives consisting of terpene compounds of natural origin $(\alpha-$ pinene, menthol, and eugenol) or colloidal silver, and these four new films were studied and compared. The best film was also mechanically stabilized with a medical net in order to form a medicinal patch that can be used for the treatment of, e.g., EB (Epidermolysis bullosa), burns, eczema, acne, and abrasions. It should be emphasized that such patches containing terpenic compounds of natural origin have not yet been described in the literature. The purpose of these films will be not only to protect against the development of infection but also to provide adequate hydration and accelerate the regeneration and healing of the skin. 


\section{Experimental}

Raw materials

In the preparation of the polysaccharide films, the following raw materials were used: starch (technical grade, Nowamyl S.A. Nowogard, Poland, CAS number 9005-25-8); monohydrate citric acid (analytical grade, Chempur, Poland, CAS number 5949-29-1); glycerol (analytical grade, Chempur, Poland, CAS number 56-81-5); carboxymethyl cellulose-CMC (degree of substitution 0.7, average molecular weight, $\overline{\mathrm{M}}_{\mathrm{n}}^{\mathrm{n}}, 250 \cdot 10^{3} \mathrm{~g} / \mathrm{mol}$, technical grade, Pronicel Sp. Z o. o., Poland, CAS number 9000-11-7); and carboxymethyl starch-CMS (CAS number 9057-06-1). The latter compound was prepared according to the method described in the literature (Spychaj et al. $2013 \mathrm{~b}$, a), with degree of substitution 0.8 , and average molecular weight $680 \cdot 10^{3} \mathrm{~g} / \mathrm{mol}$, both determined according to the methods described below. The following additives to the film compositions were used: colloidal silver (analytical grade, Alter Medika, Poland, CAS number 7440-22-4); $\alpha$-pinene (98\%, Sigma-Aldrich, Poland, CAS number 80-56-8); menthol (99\%, Sigma-Aldrich, Poland, CAS number 2216-51-5); and eugenol ( $\geq 98 \%$, Sigma-Aldrich, Poland, CAS number 97-53-0). All chemicals required for this work were commercially available and used as received. The medical net-Premilene ${ }^{\circledR}$ Mesh-used for converting the optimal film to a patch, was produced by B. Braun Melsungen AG, Germany.

Determination of the degree of substitution for CMS

The degree of substitution, DS, was measured according to the method described in the literature (Zdanowicz and Spychaj 2014). The CMS sample was moisturized in $1 \mathrm{~mL}$ of ethanol and then dissolved in $50 \mathrm{~mL}$ of distilled water. Next, $20 \mathrm{~mL}$ of $0.187 \mathrm{M}$ aqueous solution of $\mathrm{NH}_{4} \mathrm{Cl}$ was added to neutralize the $\mathrm{pH}$ of the mixture, and then the whole was poured into the flask with $50 \mathrm{~mL}$ of $\mathrm{CuSO}_{4}(0.039 \mathrm{M}$ solution). After $15 \mathrm{~min}$, water was added to the slurry, the contents were filtered, and the filtrate was titrated with EDTA solution.
Determination of the number average molecular weight for CMS

The number average molecular weight of the CMS was determined using Gel Permeation Chromatography (GPC) analysis. For this purpose, use was made of the Shodex OHpak SB-806 M MQ column with Shodex OHpak SB-G pre-column in the Merck Hitachi Liquid Chromatograph (pump L-7100, interface D-7000) with RI detector (Merck LaChrom RI L-7490). Moreover, dextran standards for the chromatographic column calibration with sodium nitrate solution $(0.1 \mathrm{M})$ as eluent (flow rate $0.5 \mathrm{~mL} / \mathrm{min}$ ) were applied.

The preparation of polysaccharide-based films

The polysaccharide-based films were prepared by the method of outpour of a solution followed by solvent evaporation. The following raw materials were introduced into the glass reactor with the capacity of 250 $\mathrm{cm}^{3}: 200 \mathrm{~g}$ of deionized water, glycerol, citric acid, and $5 \mathrm{~g}$ of polysaccharides added according to the combinations presented in Table 1 . These included starch, mixtures of starch with CMS and/or CMC, and mixtures of CMS with CMC. Next, the mixture was

Table 1 Components of the produced polysaccharide-based films

\begin{tabular}{|c|c|c|c|c|c|c|c|c|c|}
\hline \multirow[b]{2}{*}{ Film names } & \multicolumn{5}{|c|}{ Polysaccharide content [wt $\%]$} & \multicolumn{4}{|c|}{$\begin{array}{l}\text { Additives } \\
\text { [wt } \%]\end{array}$} \\
\hline & CMS & $\mathrm{CMC}$ & $\mathrm{S}$ & $\mathrm{CA}$ & G & $\mathrm{Ag}$ & $\mathrm{P}$ & M & $\mathrm{E}$ \\
\hline I & - & - & 5 & - & 3 & - & - & - & - \\
\hline II & 2.5 & - & 2.5 & 1.5 & 3 & - & - & - & - \\
\hline III & - & 2.5 & 2.5 & 1.5 & 3 & - & - & - & - \\
\hline IV & 1.25 & 1.25 & 2.5 & 1.5 & 3 & - & - & - & - \\
\hline $\mathrm{V}$ & 2.5 & 2.5 & - & 3 & 3 & - & - & - & - \\
\hline VI & 2.5 & 2.5 & - & 3 & 10 & - & - & - & - \\
\hline VII & 2.5 & 2.5 & - & 3 & 15 & - & - & - & - \\
\hline VIII & 2.5 & 2.5 & - & 3 & 3 & 3 & - & - & - \\
\hline IX & 2.5 & 2.5 & - & 3 & 3 & - & 3 & - & - \\
\hline$X$ & 2.5 & 2.5 & - & 3 & 3 & - & - & 3 & - \\
\hline XI & 2.5 & 2.5 & - & 3 & 3 & - & - & - & 3 \\
\hline
\end{tabular}

where: wt\%-weight percent, CMS—carboxymethyl starch, CMC - carboxymethyl cellulose, S-starch, CA-citric acid, $\mathrm{G}-\mathrm{glycerol}, \mathrm{Ag}$ - colloidal silver, $\mathrm{P}-\alpha$-pinene, $\mathrm{M}-$ menthol, E - eugenol 
stirred until a homogeneous solution was obtained, and for the composition with starch, stirring was made in a water bath at a temperature of $90{ }^{\circ} \mathrm{C}$. Following that, the additive compounds (colloidal silver, $\alpha$ pinene, menthol, and eugenol) were introduced individually. The mixture was stirred for $30 \mathrm{~min}$ until a homogeneous mixture was obtained, and next this mixture was outpoured into the Teflon mold. The mold was put into a drying oven for $48 \mathrm{~h}$ at $70{ }^{\circ} \mathrm{C}$, and the prepared film was then taken from the mold.

Methods of testing the properties

of the polysaccharide-based films

\section{Tensile strength}

The tensile strengths of the fabricated films were measured using the INSTRON testing machine. The initial length of the sample was $50 \mathrm{~mm}, 10 \mathrm{~mm}$ wide, and about $0.2 \mathrm{~mm}$ thick. The speed of the mobile clamp was $10 \mathrm{~mm} / \mathrm{min}$. Seven samples of each material type were tested (Roy et al. 2012; Antosik and Wilpiszewska 2018).

\section{Moisture absorption}

Moisture absorption tests were performed for each film as follows. Three samples $(1.5 \times 1.5 \mathrm{~cm})$ were prepared and placed for two weeks in a desiccator to dry. Dry samples were weighed and subsequently transferred to a climatic chamber $(55 \pm 2 \%$ humidity, $\left.25 \pm 2{ }^{\circ} \mathrm{C}\right)$. The samples were then weighed after being in the climate chamber for 3, 5, 7, 24, 48, and $72 \mathrm{~h}$. Moisture absorption was calculated using the following equation (Ghanbarzadeh and Almasi 2011; Wilpiszewska et al. 2015):

$A_{t}=\frac{M_{t}-M_{0}}{M_{0}} \cdot 100 \%$

where: $\mathrm{A}_{\mathrm{t}}-$ moisture absorption after time $\mathrm{t}[\%] ; \mathrm{M}_{0^{-}}$ mass of dry sample $[\mathrm{g}] ; \mathrm{M}_{\mathrm{t}}-$ mass of sample after time $\mathrm{t}$ [g].

\section{Solubility in water}

Solubility in water was evaluated for each film. Three samples $(1.5 \times 1.5 \mathrm{~cm})$ were prepared and placed for two weeks in the desiccator to dry. Dry samples were weighed and transferred to test tubes filled with $50 \mathrm{~mL}$ of distilled water. After $24 \mathrm{~h}$, the samples were dried and weighed. Solubility was calculated using the following equation (Ghanbarzadeh and Almasi 2011; Wilpiszewska et al. 2015):

$T S M=\frac{M_{1}-M_{2}}{M_{1}} \cdot 100 \%$

where: TSM-Total Soluble Matter (in water) [\%]; $\mathbf{M}_{1}$-mass of dry sample [g]; $\mathbf{M}_{2}$-mass of sample after drying [g].

\section{Swelling tests}

Swelling tests were aimed at determining the increase in mass and size of the materials. For this purpose, $4 \times 4 \mathrm{~cm}$ material samples were weighed and then placed in $50 \mathrm{~mL}$ of saline solution at room temperature for $24 \mathrm{~h}$. After this time, the test material was removed from the solution, dried on a paper towel, weighed and measured. Unfortunately, some samples disintegrated after $24 \mathrm{~h}$, which made it impossible to determine their weight and size.

\section{Wetting angle tests}

Wetting angle tests were performed using the Goniometer OCA 15EC with the sitting drop method. Measurements were made in the time range of 5-300 s. These tests were performed only for the film selected as the optimal one for further studies with the additives (film V).

\section{Microbial tests}

The antimicrobial tests were performed with the gramnegative bacteria Escherichia coli strain K12 (ACCT 25,922), gram-positive bacteria Staphylococcus epidermidis (ACCT 49,461), and candida yeast-Candida albicans (isolated from patients with immunodeficiency disorders from the Department of Chemical and Process Engineering, DChPE, collection). The antimicrobial activities of colloidal silver, $\alpha$-pinene, menthol, and eugenol were preliminarily investigated using the "disk agar plate diffusion method". Plate Count Agar (PCA, BioMaxima S.A, PL) for E. coli, Brain Heart Infusion Agar (BHI, BioMaxima S.A, PL) for $S$. epidermidis and Sabouraud Dextrose Agar (SDA, BTL Sp. z.o.o., PL) for C. albicans were used. The 24-h microbial cultures in the recommended 
liquid media were centrifuged at about $1000 \mathrm{rpm}$ for $10 \mathrm{~min}$. Then, the entire sediments were transferred to sterile bottles containing $0.85 \%$ sodium chloride solution. Microbial cultures were appropriately diluted to obtain an inoculation level of 0.5 in McFarland Standards (BioMerieux, France) corresponding to a cell density of approximately $1.5 \times 10^{8} \mathrm{CFU} / \mathrm{mL}$. The plates containing the microorganism media in sterile plastic Petri dishes $(\varnothing=9.0 \mathrm{~cm})$ were inoculated with $0.25 \mathrm{~mL}$ of microorganism suspensions. The sterile paper discs (Whatman No.1, diameter $5.0 \mathrm{~mm}$ ), impregnated with each substance $(10 \mu \mathrm{L} /$ disc $)$, were placed at different locations on the surface of culture plates and incubated at $37{ }^{\circ} \mathrm{C}$ for $24 \mathrm{~h}$. The disc soaked with sterile sodium chloride solution was used as a control experiment.

The zones of inhibition (ZOI) of growth around the paper discs were measured. The sensitivity to the tested agents was classified by the diameter of the inhibition halos as: not sensitive $(-)$ for diameters less than $3 \mathrm{~mm}$; sensitive ( + ) for diameters 3-6 mm; very sensitive $(++)$ for diameters larger than $6 \mathrm{~mm}$ and less than $9 \mathrm{~mm}$ and super sensitive for diameters larger than $9 \mathrm{~mm}(+++)$. Two discs per plate were used, and each plate was set up in triplicate. Additionally, the polysaccharides-based films (numbered V, VIII-XI) were cut to the size of $25 \times 25 \mathrm{~mm}$, and about $1-2 \mathrm{~mm}$ in thickness, and put directly on the agar plates with the inoculum of tested bacteria or yeast. The Petri dishes were incubated at $37^{\circ} \mathrm{C}$ for $48 \mathrm{~h}$, and, afterwards, the microbial growth-or absence of growth-around these films was determined.

\section{Results and discussion}

Mechanical and physical properties of fabricated films

In order to select the optimal polysaccharide film composition, 7 film variants (without additives) were produced that differed in the content of polysaccharides (CMS, CMC, S) and the amount of cross-linker compound (citric acid, CA) and plasticizer (glycerol, G). These films were examined in terms of tensile strength, Young's modulus and elongation at break. In addition, solubility in water, moisture sorption (after $120 \mathrm{~h}$ ), and swelling was determined. The results of these tests are collected in Table 2. For the selection of the optimal polysaccharide film, the correlation of all tested properties was taken into account. (We decided that for films containing additives the mechanical properties will not be measured.)

It was established that due to specific requirements (use for medical purposes) more emphasis should be placed on moisture sorption (after $120 \mathrm{~h}$ ) and swelling. Despite relatively good mechanical results, films containing starch (I-IV) were characterized by low moisture absorption. During the swelling tests, the presence of starch in these materials caused the films to significantly increase in size in one direction only, and simultaneously, no volume swelling was observed. This phenomenon could damage the medical patch composed of such a film during use. This linear increase in size is related to the layered structure of starch and the structure of the polysaccharides. Water molecules coming into contact with the polysaccharide chains increase the volume of the film

Table 2 The mean measured properties of the produced polysaccharide-based films

\begin{tabular}{|c|c|c|c|c|c|c|}
\hline \multirow[b]{2}{*}{$\begin{array}{l}\text { Film } \\
\text { number }\end{array}$} & \multicolumn{3}{|c|}{ Mechanical properties } & \multicolumn{3}{|l|}{ Moisture } \\
\hline & $\begin{array}{l}\text { Elongation at } \\
\text { break [\%] }\end{array}$ & $\begin{array}{l}\text { Young's modulus } \\
\text { [MPa] }\end{array}$ & $\begin{array}{l}\text { Tensile strength } \\
{[\mathrm{MPa}]}\end{array}$ & $\begin{array}{l}\text { Solubility in water } \\
{[\%]}\end{array}$ & $\begin{array}{l}\text { sorption after } \\
120 \mathrm{~h}[\%]\end{array}$ & $\begin{array}{l}\text { Swelling } \\
\text { [wt } \%]\end{array}$ \\
\hline I & $43.0 \pm 0.1$ & $49.5 \pm 0.1$ & $15.9 \pm 0.1$ & $36 \pm 1$ & $13 \pm 1$ & $156 \pm 1$ \\
\hline II & $33.8 \pm 0.1$ & N/A & $0.7 \pm 0.1$ & $62 \pm 1$ & $16 \pm 1$ & $266 \pm 1$ \\
\hline III & $37.2 \pm 0.1$ & $10.2 \pm 0.1$ & $5.9 \pm 0.1$ & $60 \pm 1$ & $17 \pm 1$ & $170 \pm 1$ \\
\hline IV & $59.0 \pm 0.1$ & $25.7 \pm 0.1$ & $7.2 \pm 0.1$ & $51 \pm 1$ & $15 \pm 1$ & $165 \pm 1$ \\
\hline V & $22.1 \pm 0.1$ & $4.8 \pm 0.1$ & $1.9 \pm 0.1$ & $73 \pm 1$ & $19 \pm 1$ & $182 \pm 1$ \\
\hline VI & N/A & N/A & $0.3 \pm 0.1$ & $80 \pm 1$ & $23 \pm 1$ & $185 \pm 1$ \\
\hline VII & N/A & N/A & $<0.1 \pm 0.01$ & $84 \pm 1$ & $25 \pm 1$ & $190 \pm 1$ \\
\hline
\end{tabular}


CAleft: $50.8^{*}$
CA right: 51.7

$5 s$

CAleft: $49.9^{\circ}$

$10 \mathrm{~s}$
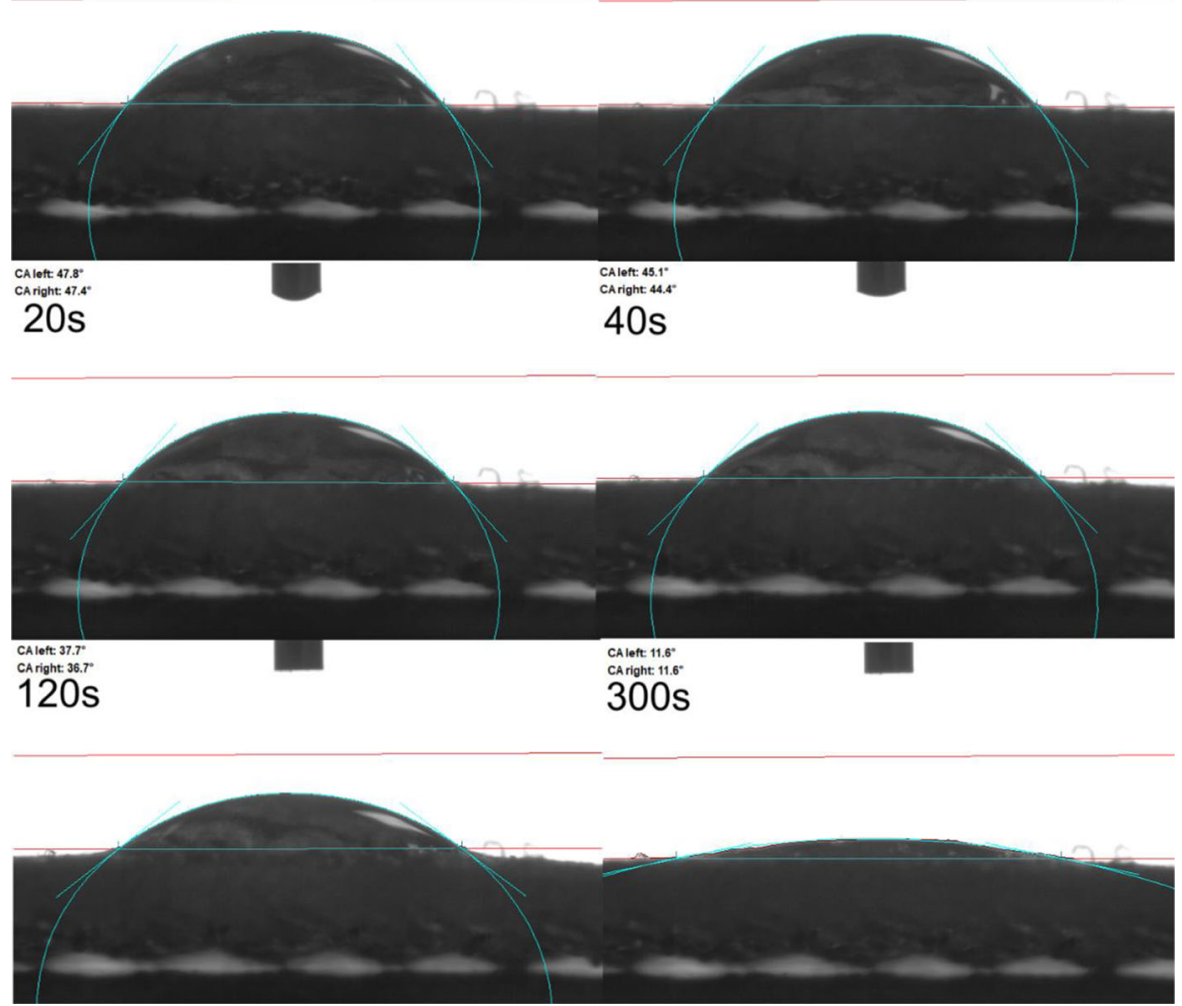

Fig. 1 Wetting angle test results for film $\mathrm{V}$ after various times of contact

matrix. Then, the absorption of water molecules increases and the layers undergo separation in one direction (Mahomed et al. 2017). In contrast, filmsVVII, which did not contain starch, were characterized by low and very low values of the mechanical properties, which may prevent proper use of these films.

Moreover, it was observed for films with high concentration of glycerol (films VI and VII), that they were too delicate and degenerated by simply rubbing the film with gentle finger pressure. Hence, we decided that the optimal film for the medical applications in the form of patches and for the introduction of additives (colloidal silver, $\alpha$-pinene, menthol, and eugenol) will be film $\mathrm{V}$, which contains $3 \mathrm{wt} \%$ of glycerol of the dry polysaccharide mass. Therefore, we decided to prepare this film with a medical net inside, as discussed below, to improve its stability and, thus, this modification allows this film to be used in medical patches.

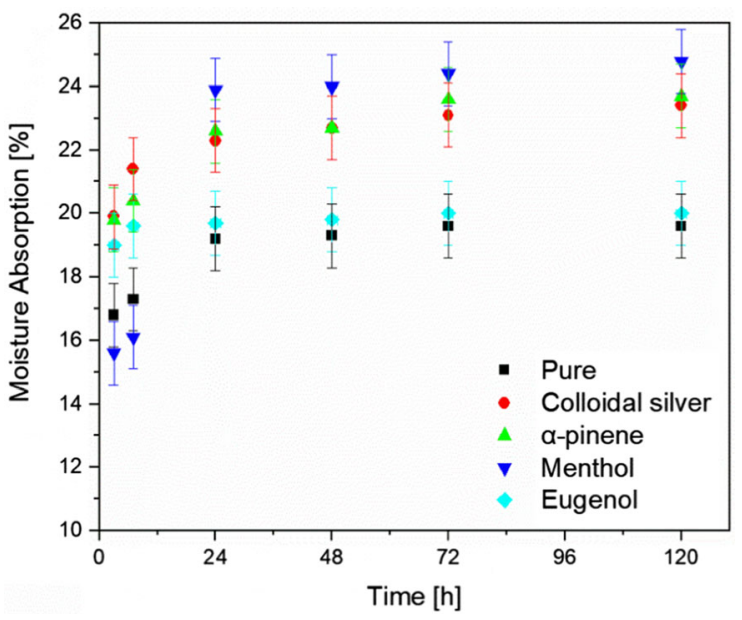

Fig. 2 Influence of different additives on the moisture absorption of films VIII-XI, based on film V (the "pure" material), at a temperature of $25 \pm 2{ }^{\circ} \mathrm{C}$ 
Wetting properties

The literature describes that the contact angle is a quantitative measure of the wetting of the solid (the film) by a liquid (water), and so the wetting angle tests were performed for film $\mathrm{V}$, selected as the most suitable for further studies with the additives (Fig. 1). The value of the contact angles corresponds to the value gained at zero time, i.e., it is the initial contact angle at first droplet contact. Films characterized by good wetting of their surfaces by water should have a contact angle of less than $90^{\circ}$ in order to be able to be used as wound dressings (Basiak et al. 2018). The literature also indicates that this contact angle is dependent on the amount of glycerol added to the film composition. Generally, the more glycerol, the lower the wetting angle and the better the water distribution on the film surface. These studies were performed for the contents of 33 and $50 \%$ glycerol (Basiak et al. 2018).

The wetting angle tests showed that the contact angle was $51.25^{\circ}$ (average of two measurements, 50.8 and 51.7) after $5 \mathrm{~s}$ of applying the drop, which suggests very good wetting of the obtained materials. It can also be seen that by extending the contact time of the drop with the surface, the drop material is completely absorbed. This phenomenon is very desirable considering the medical use of the film as a patch.

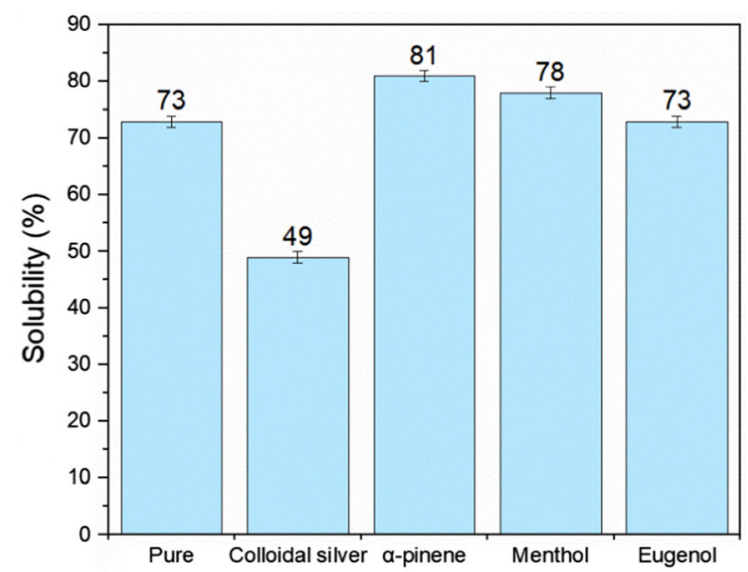

Fig. 3 Influence of different additives on the solubility of the films based on "pure" film V
Incorporating additives in the films

In the second stage of our studies the selected film V (the "pure" material) was modified by the individual additions of the appropriate amounts of the additivescolloidal silver, $\alpha$-pinene, menthol, and eugenol-to form films VIII-XI (Table 1) in order to study the effect of the appropriate additive on moisture absorption, solubility in water, swelling, and antimicrobial activity.

\section{Moisture absorption of modified films}

Figure 2 presents the influence of the different additives on the moisture absorption of modified films based on film V. It is noticeable that in all cases, the additives generally caused an increase in the moisture absorption in comparison to the pure film V. The film with menthol (X) exhibited a lower moisture absorption at the beginning of the measurements (up to $7 \mathrm{~h}$ ), and then it showed the highest values (about 24-25\%) among the compositions tested. This may be due to the specific properties of this compound (at room temperature it is a solid and forms white crystals), so that the film is in the form of agglomerates (Daryadel et al. 2018; Nesil et al. 2019). The presence of menthol agglomerates in the film can lead to an uneven absorption of moisture, and, consequently, can lead to fine cracks in the film and increased water absorption. The explanation for this behavior of the menthol film, however, requires further research.

For the film with colloidal silver as the additive (VIII) and for the film with $\alpha$-pinene (IX), the increase in the moisture absorption to $23-25 \%$ (from $19 \%$ for pure film V) was observed. The addition of eugenol (film XI) did not have a significant influence on the moisture absorption after $120 \mathrm{~h}$, and has a similar ability to absorb moisture as the base film V. Taking this into account, it can be assumed that both films will have similar durability when used to absorb wound exudates. However, in the case of other films, it can be assumed that they will be characterized by greater durability due to the increased ability to absorb water. Therefore, the application time per wound may be longer for them. These observations, however, require further study. 
Table 3 Results of swelling tests for the films with additives (VIII-XI) and without (V)

\begin{tabular}{llllllll}
\hline $\begin{array}{l}\text { Film } \\
\text { number }\end{array}$ & $\begin{array}{l}\text { Weight } \\
\text { before }[\mathrm{g}]\end{array}$ & $\begin{array}{l}\text { Weight } \\
\text { after [g] }\end{array}$ & $\begin{array}{l}\text { Weight } \\
\text { gain [\%] }\end{array}$ & $\begin{array}{l}\text { Size } \\
\text { before [cm] }\end{array}$ & $\begin{array}{l}\text { Size } \\
\text { after [cm] }\end{array}$ & $\begin{array}{l}\text { Size } \\
\text { gain [ \%] }\end{array}$ & Disintegration \\
\hline $\mathrm{V}$ & $0.667 \pm 0.001$ & $1.215 \pm 0.001$ & $182.16 \pm 0.01$ & $4 \pm 0.1$ & $4.4 \pm 0.1$ & $110 \pm 0.1$ & - \\
$\mathrm{VIII}$ & $1.181 \pm 0.001$ & $3.231 \pm 0.001$ & $177.69 \pm 0.01$ & $4 \pm 0.1$ & $4.8 \pm 0.1$ & $120 \pm 0.1$ & - \\
$\mathrm{IX}$ & $2.619 \pm 0.001$ & $6.7528 \pm 0.001$ & $257.82 \pm 0.01$ & $4 \pm 0.1$ & $5.6 \pm 0.1$ & $140 \pm 0.1$ & - \\
$\mathrm{X}$ & $1.275 \pm 0.001$ & $2.548 \pm 0.001$ & $199.84 \pm 0.01$ & $4 \pm 0.1$ & $4.7 \pm 0.1$ & $118 \pm 0.1$ & - \\
$\mathrm{XI}$ & $1.628 \pm 0.001$ & $3.189 \pm 0.001$ & $195.88 \pm 0.01$ & $4 \pm 0.1$ & $4.8 \pm 0.1$ & $120 \pm 0.1$ & - \\
\hline
\end{tabular}



Fig. 4 Antimicrobial activity as the growth of inhibition zone $[\mathrm{mm}]$ of the pure components-colloidal silver, terpenes $(\alpha-$ pinene, menthol and eugenol), and control (sodium chloride) determined by the agar plate diffusion method

Water solubility of the films

The solubility in water of the prepared polysaccharide films with different additives is presented in Fig. 3. Firstly, it should be emphasized that the studied samples maintained their integrity-did not break or dissolve during the solubility test. Films IX ( $\alpha$-pinene) and $\mathrm{X}$ (menthol) exhibited an increased solubility in comparison to the film without additives (film V). Only the addition of colloidal silver caused a significant decrease in the solubility in water of the obtained film. This may be caused by the increase in the network density of this cross-linked film as the introduction of the colloidal silver to the film produced a more compact film structure.
Swelling tests

Table 3 summarizes the results obtained during the swelling tests for films V and VIII-XI. The table shows that the mass increase and size gain (volume increase) was the highest for film IX, which was obtained with $\alpha$-pinene as the additive. Films with other additives showed these two parameters to be about similar in value or slightly higher than for the pure film V. This comparison shows that $\alpha$-pinene film is best suited for the role of the patch. The increase in volume with simultaneous absorption of moisture (wound exudates) effectively produces dual beneficial properties-a "protective cushion" and "a soft compress". The slightly inferior values of volume and mass increases for other films with additives do not preclude their use as patches, because unlike film IX, they may have better properties of inhibiting the growth of various microorganisms. At the same time, it should be emphasized that none of the examined films disintegrated during these tests.

\section{Microbial tests}

The results obtained in the microbial tests presented in this work were consistent with the literature data (Leite et al. 2007; Karapandzova et al. 2012; Zeng et al. 2012; Silva et al. 2012), and these results are the proof of antibacterial and anti-yeast activities of $\alpha$ pinene and eugenol. Moreover, these tests also showed that the colloidal silver exhibited a low antimicrobial activity, only against such microorganisms as grampositive $S$. epidermidis and yeast $C$. albicans, whereas menthol was active against gram-positive and gramnegative bacteria. Additionally, no inhibitory effect on the tested microorganisms was observed for the sodium chloride solution used as a control during the 
tests (Fig. 4). We did not show the results of the zone of inhibition (ZOI) for $\alpha$-pinene and menthol against $S$. epidermidis and $C$. albicans, because these two terpenes were not active against these microorganisms. According to the literature data (Semeniuc et al. 2017) the size of the ZOI varies depending on bacterial strain used for the tests. The mechanism of the action of essential oils remains unclear, and some studies have shown that, e.g., phenols, such as carvacrol and eugenol, disrupt the cellular membrane and react with the active sites of enzymes. All enzymes play a key role in the emergence of resistance, which could be an explanation of the observed differences.

The lowest concentration of an antibacterial agent necessary to inhibit visible growth of microorganism is defined as MIC (Minimum Inhibitory Concentration). These minimum concentrations were found for eugenol and $\alpha$ - and $\beta$-pinene, and they depend on the source of terpene compound, the strains of microorganism, and the methods used (Leite et al. 2007). Additionally, the MIC values of pinene depend on the type of enantiomers-only positive exhibited antimicrobial effect (Silva et al. 2012). Considering the above arguments, and the many variables encountered, a comparison of the antimicrobial activity results obtained by varied research teams is very difficult. However, literature data show (Leite et al. 2007; Pavesi et al. 2018) that eugenol provided the most intense antibacterial effect (MIC values $>5 \mu \mathrm{L}$ / $\mathrm{mL}$ and with growth inhibition zones higher than $10 \mathrm{~mm}$ ). Similar results are presented for menthol, which has been regarded as a potential source of a natural antimicrobial compound against staphylococcal infections, including MRSA strain (Horváth and Koščová 2017). It has been proven that menthol is a safe product that can be used topically or orally to treat minor aches, pains, inflammation, and congestion.

By contrast colloidal silver has caused much controversy. Due to its low stability in solvents, it found only limited applications. The antibacterial action of colloidal silver against gram-negative and gram-positive pathogens as well as drug resistance is not entirely clear (Dakal et al. 2016). The results from this study indicated that colloidal silver presented a lack of action against gram-negative bacteria while Afonina et al. (2010) reported that these bacteria are more susceptible to the action of colloidal silver. Recently published studies showed that prolonged exposure of microorganisms to colloidal silver may result in the development of their resistance (Graves et al. 2015). Additionally, it was reported exposure of human cells to silver nanoparticles induces cytotoxicity, genotoxicity, and inflammatory response in human cells (Maneewattanapinyo et al. 2011). These results indicate that caution should be taken into account regarding the use of silver as the antimicrobial agent.

To the best of our knowledge, the mechanism of terpenes action has not been explained. It is hypothesized that terpene compounds inhibit internal enzymatic reactions or disrupt the outer cell membranes of microorganisms (Romeo et al. 2008). It is well known that the biocidal character of silver is better investigated and understood. Silver ions interact with the bacterial cell envelope and with molecules inside the cell (e.g., nucleic acids and enzymes) or produced reactive oxygen species (Kędziora et al. 2018).

The results of the microbial tests performed on the control film (pure film V) and on films with additives (VIII-XI) were collected in Table 4.

As expected, no inhibition zones against microorganisms were observed for the control film V. The results obtained for the other films indicated that the antimicrobial activities of the tested films depended on the type of microorganism as well as on the terpene compound used as the additive. It was assumed that the main reason for the varied susceptibilities of the tested microorganisms to the action of the films were
Table 4 Average growth inhibition zones around the studied films

*sd-standard deviation (the sensitivity of the organisms)

\begin{tabular}{llll}
\hline & \multicolumn{2}{l}{ Microorganisms growth inhibition zones [mm] } \\
\cline { 2 - 4 } Studied films & E. coli & S. epidermidis & C. albicans \\
\hline $\mathrm{V}$ & $0.0 \pm 0.0^{*}(-)$ & $0.0 \pm 0.0(-)$ & $0.0 \pm 0.0(-)$ \\
VIII (silver) & $7.1 \pm 1.0(++)$ & $4.9 \pm 1.0(+)$ & $0.0 \pm 0.0(-)$ \\
IX ( $\alpha$-pinene) & $7.6 \pm 1.0(++)$ & $0.0 \pm 0.0(-)$ & $0.0 \pm 0.0(-)$ \\
X (menthol) & $9.8 \pm 0.5(+++)$ & $0.0 \pm 0.0(-)$ & $0.0 \pm 0.0(-)$ \\
XI (eugenol) & $11.5 \pm 1.0(+++)$ & $8.25 \pm 1.5(++)$ & $20.5 \pm 0.5(+++)$ \\
\hline
\end{tabular}




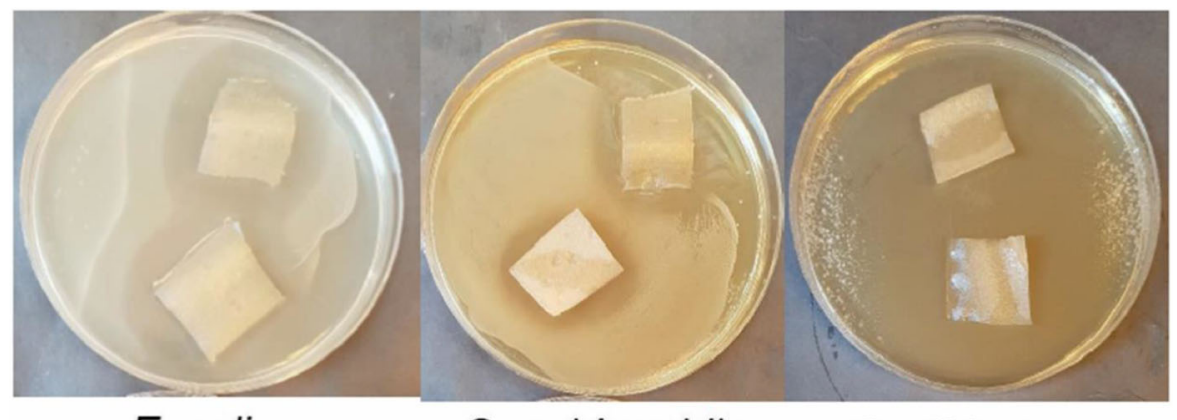

E. coli

S. epidermidis

C. albicans

Fig. 5 Samples of film XI (with $3.0 \mathrm{~g}$ of eugenol) evaluated by inhibition of growth against E. coli, S. epidermidis bacteria, and yeast, C. albicans

caused by differences in the composition and structure of the cell envelopes (e.g. lipid and protein composition of membranes) and species-specific physiology. Comparing the microorganisms, it can be concluded that yeast, $C$. albicans, and gram-negative E. coli bacteria, were more sensitive to all tested substances since inhibition zones were observed and these zones were significantly larger than those obtained for the others microorganisms. During our studies, the best overall antimicrobial activity was exhibited by film XI (the film containing $3.0 \mathrm{~g}$ of eugenol). For this film, the inhibition of microorganism growth was also

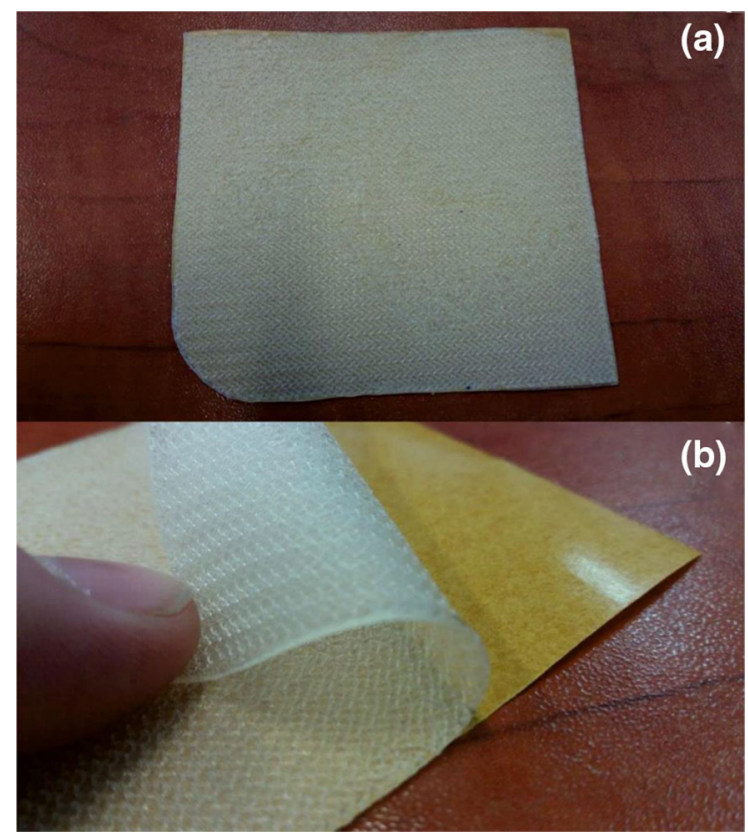

Fig. 6 The appearance of film $\mathrm{V}$ with the medical net inside: (a) and (b) observed (Fig. 5). The broad-spectrum of the activity of eugenol against a varied group of microorganisms is confirmed by the results described in the literature (Marchese et al. 2017). However, the mechanism of action may require further investigations.

Unexpectedly, the films enriched with silver, $\alpha$ pinene, and menthol did not present anti-yeast activity. It must be emphasized that films containing eugenol, $\alpha$-pinene, menthol, and colloidal silver showed almost the same antibacterial activities, respectively, in comparison with those of the pure substances (Fig. 4). It can be assumed that various tested agents diffuse very easily through polymer composite films.

Due to the increase of bacterial resistance to antibiotics, there is considerable interest in developing novel natural antimicrobial agents for medical applications. It is noteworthy that components of essential oils derived from plants (mainly terpene compounds) do not have an influence on somatic human cells. Moreover, these compounds are used very often as antioxidant agents (Romeo et al. 2008). It was shown that eugenol from clove had high activity against some representative skin microorganisms, especially $S$. epidermidis and C. albicans. The latter microorganism is a commensal fungus that colonizes healthy human skin and the reproductive tract. However, for some immunocompromised people $C$. albicans is a predominantly opportunistic fungal pathogen, causing disseminated candidiasis and chronic mucocutaneous candidiasis (CMC).

Over the past few years, various polymers enriched with natural substances (such as, isolates from marjoram, cinnamon, and clove) have been extensively investigated. In order to form antibacterial materials, 


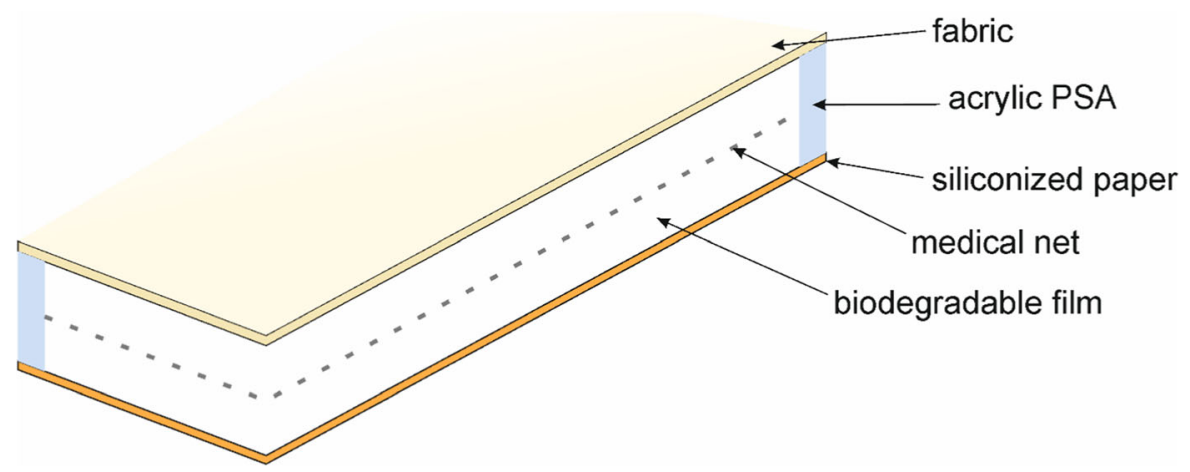

Fig. 7 The patch design

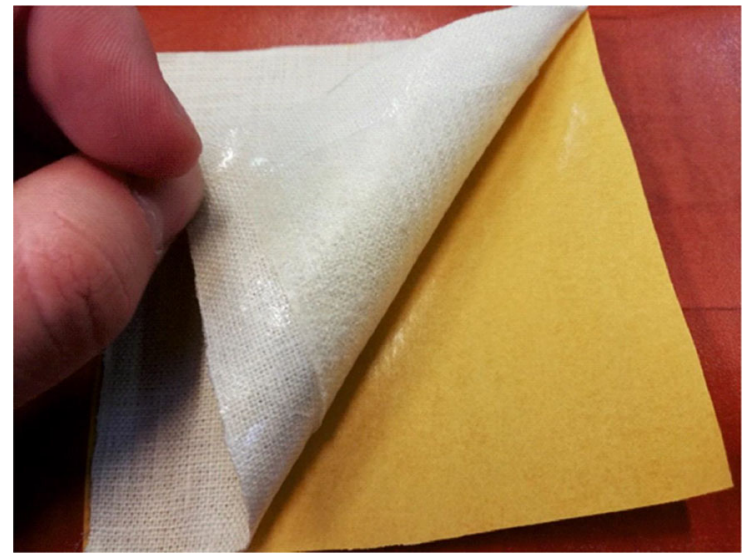

Fig. 8 The patch prototype

methyl-cellulose, chitosan, gelatin, and starch films were used (Fisher and Phillips 2008; SánchezGonzález et al. 2011; Hernández-Ochoa et al. 2012; Shaaban et al. 2014; Wu et al. 2017). SánchezGonzález et al. defined various factors that can affect the antimicrobial action of films (Sánchez-González et al. 2011). These factors are: the nature of substances (non-volatile or volatile), characteristics of the film matrix, and the method of film preparation. Our results confirmed these claims, so further studies are needed, before producing patches with the incorporation of terpene compounds or silver. The exact mechanism of their action must be fully understood and effective dosage should be determined.

The design and preparation of patch prototype

The optimal film chosen (V) was formed on the medical net to strengthen its mechanical properties, and is shown in Fig. 6.
The film obtained with the medical mesh inside was glued onto the fabric with an acrylate pressuresensitive adhesive (acrylic PSA) so that the glued fabric attached to the hydrogel could remain attached to the body. The whole was protected with siliconized paper. The design of this patch is depicted in Fig. 7, and the self-adhesive protective patch prototype was prepared and is shown in Fig. 8. It is flexible and able to take the shape and size of the area on the human body on which it is placed.

\section{Conclusions}

This work has shown that polysaccharide films based on starch, CMS and CMC together with glycerol, citric acid, and imbued with terpene compounds of natural origin can be good materials for the preparation of medicinal patches. The properties of these films are comparable to-or even better than-those same polysaccharide materials containing colloidal silver.

Moisture absorption tests showed that colloidal silver and $\alpha$-pinene films had comparable results, while much better results were obtained for menthol. On the other hand, the addition of eugenol did not significantly change the moisture absorption value compared to the pure film without additives. The parameter of moisture absorption by the films is very important, because the designed patches should absorb moisture from infected or damaged places on the skin. As a result, the development of various infections can be inhibited, and as a consequence, the treatment will be accelerated.

Tests on the water solubility of the obtained films showed that none of the films fell apart but the films 
with terpenes showed increased solubility in comparison to the film with colloidal silver, which is not favorable. On the other hand, the dissolution of materials containing terpene compounds may release these molecules from the film structure, which will be able to directly affect the infected skin, and, consequently-considering their therapeutic effect-accelerate the healing process.

The mass and volume increases were the highest for film IX ( $\alpha$-pinene as the additive). Films with other additives, including colloidal silver, showed lower values for these two parameters but slightly higher than for pure film V (without any additives). These results confirmed that with the help of appropriate terpene compounds it is possible to obtain comparable or better materials for preparing patches than with colloidal silver. The increase in volume with simultaneous absorption of moisture (wound exudates) makes this film behave simultaneously like a "protective cushion" as well as a "soft compress".

During the microbiological tests, it was found that the film with eugenol showed the best antimicrobial activity. Films with other terpenes, however, showed similar antimicrobial activity as the film with colloidal silver. Moreover, test results should allow them to be used as patches for the treatment of EB (Epidermolysis bullosa), burns, eczema, acne, and abrasions. These films should not only protect against the development of infections but also, with the regenerative properties of the terpenes, provide adequate hydration and accelerate the regeneration and healing of the skin.

Considering the mechanical properties of this kind of terpene-included film, the medical patch based on it should be prepared with the help of a medical net. In the future, taking into account the medical uses of the developed patches, the overall analysis of biocompatibilities including cytocompatibility, tissue compatibility or hemocompatibility should also be performed. The great benefit of using terpene compounds as additives for materials intended to serve as patches should also be emphasized, since these compounds are substances of natural origin obtained from plants, are relatively cheap and renewable raw materials.

\section{Declarations}

Conflict of interest The authors declared that they have no conflict of interst.
Ethical approval This study following Compliance with Ethical Standards; this study does not involve human participants, animals, and potential conflicts of interest.

Open Access This article is licensed under a Creative Commons Attribution 4.0 International License, which permits use, sharing, adaptation, distribution and reproduction in any medium or format, as long as you give appropriate credit to the original author(s) and the source, provide a link to the Creative Commons licence, and indicate if changes were made. The images or other third party material in this article are included in the article's Creative Commons licence, unless indicated otherwise in a credit line to the material. If material is not included in the article's Creative Commons licence and your intended use is not permitted by statutory regulation or exceeds the permitted use, you will need to obtain permission directly from the copyright holder. To view a copy of this licence, visit http://creativecommons.org/licenses/by/4.0/.

\section{References}

Afonina IA, Kraeva LA, Tseneva GI (2010) Bactericidal activity of colloidal silver against grampositive and gramnegative bacteria. Antibiot i Khimioterapiia 55:11-13

Alberta Araújo M, Cunha AM, Mota M (2004) Enzymatic degradation of starch-based thermoplastic compounds used in protheses: identification of the degradation products in solution. Biomaterials 25:2687-2693. https://doi.org/10. 1016/j.biomaterials.2003.09.093

Ali B, Al-Wabel NA, Shams S et al (2015) Essential oils used in aromatherapy: a systemic review. Asian Pac J Trop Biomed 5:601-611. https://doi.org/10.1016/j.apjtb.2015. 05.007

Antosik AK, Wilpiszewska K (2018) Natural composites based on polysaccharide derivatives: preparation and physicochemical properties. Chem Pap 72:3215-3218. https://doi. org/10.1007/s11696-018-0550-3

Antosik AK, Wilpiszewska K, Wróblewska A et al (2017) Fragrant starch-based films with limonene. Curr Chem Lett. https://doi.org/10.5267/j.ccl.2017.2.002

Bachiega TF, de Sousa JPB, Bastos JK, Sforcin JM (2012) Clove and eugenol in noncytotoxic concentrations exert immunomodulatory/anti-inflammatory action on cytokine production by murine macrophages. J Pharm Pharmacol 64:610-616. https://doi.org/10.1111/j.2042-7158.2011. 01440.x

Basiak E, Lenart A, Debeaufort F (2018) How glycerol and water contents affect the structural and functional properties of starch-based edible films. Polymers 10:412. https:// doi.org/10.3390/polym10040412

Basta AH, El-Saied H, Lotfy VF (2013) Performance of rice straw-based composites using environmentally friendly polyalcoholic polymers-based adhesive system. Pigment Resin Technol 42:24-33. https://doi.org/10.1108/ 03699421311288733

Bialik-Wąs K, Pielichowski K (2011) Polimerowe opatrunki hydrożelowe dla zastosowań biomedycznych. Czas Tech 10:39-52 
da Silva ACR, Lopes PM, de Azevedo MMB et al (2012) Biological Activities of a-Pinene and $\beta$-Pinene Enantiomers. Molecules 17:6305-6316. https://doi.org/10.3390/ molecules 17066305

Dakal TC, Kumar A, Majumdar RS, Yadav V (2016) Mechanistic basis of antimicrobial actions of silver nanoparticles. Front Microbiol. https://doi.org/10.3389/fmicb.2016. 01831

Daryadel S, Atmaca U, Taslimi P et al (2018) Novel sulfamate derivatives of menthol: synthesis, characterization, and cholinesterases and carbonic anhydrase enzymes inhibition properties. Arch Pharm (weinheim) 351:1800209. https:// doi.org/10.1002/ardp.201800209

deBoer TR, Chakraborty I, Mascharak PK (2015) Design and construction of a silver(I)-loaded cellulose-based wound dressing: trackable and sustained release of silver for controlled therapeutic delivery to wound sites. J Mater Sci Mater Med 26:243. https://doi.org/10.1007/s10856-0155577-1

Drewnowska E, Antosik AK, Wróblewska A et al (2017) Fragrant films on the basis of potato starch. Polish J Chem Technol 19:88-92. https://doi.org/10.1515/pjct-2017-0033

El-Saied H, Basta AH, Abdel-Hadi AK, Hosny WM (1994) Metal chelates with some cellulose derivatives. Part I. Preparation and characterization of chromium (III)-carboxymethyl cellulose complexes. Polym Int 35:27-33. https://doi.org/10.1002/pi.1994.210350102

Fisher K, Phillips C (2008) Potential antimicrobial uses of essential oils in food: is citrus the answer? Trends Food Sci Technol 19:156-164. https://doi.org/10.1016/j.tifs.2007. 11.006

Gebelein CG, Cheng TC, Yang VC (1991) Cosmetic and Pharmaceutical Applications of Polymers. Springer, US, New York

Ghanbarzadeh B, Almasi H (2011) Physical properties of edible emulsified films based on carboxymethyl cellulose and oleic acid. Int J Biol Macromol 48:44-49. https://doi.org/ 10.1016/j.ijbiomac.2010.09.014

Graves JL, Tajkarimi M, Cunningham Q et al (2015) Rapid evolution of silver nanoparticle resistance in escherichia coli. Front Genet. https://doi.org/10.3389/fgene.2015. 00042

Guo J-H, Skinner G, Harcum W, Barnum P (1998) Pharmaceutical applications of naturally occurring water-soluble polymers. Pharm Sci Technolo Today 1:254-261. https:// doi.org/10.1016/S1461-5347(98)00072-8

Hassabo AG, Nada AA, Ibrahim HM, Abou-Zeid NY (2015) Impregnation of silver nanoparticles into polysaccharide substrates and their properties. Carbohydr Polym 122:343-350. https://doi.org/10.1016/j.carbpol.2014.03. 009

Hassan B, Chatha SAS, Hussain AI et al (2018) Recent advances on polysaccharides, lipids and protein based edible films and coatings: a review. Int $\mathrm{J}$ Biol Macromol 109:1095-1107. https://doi.org/10.1016/j.ijbiomac.2017. 11.097

Hernández-Ochoa L, Macías-Castañeda CA, Nevárez-Moorillón GV et al (2012) Antimicrobial activity of chitosanbased films including spices' essential oils and functional extracts. CyTA - J Food 10:85-91. https://doi.org/10.1080/ 19476337.2011.576434
Horváth P, Koščová J (2017) In vitro antibacterial activity of mentha essential oils against staphylococcus aureus. Folia Vet 61:71-77. https://doi.org/10.1515/fv-2017-0030

Hovgaard L, Brondsted H (1996) Current applications of polysaccharides in colon targeting. Crit Rev Ther Drug Carr Syst 13:185-223. https://doi.org/10.1615/ CritRevTherDrugCarrierSyst.v13.i3-4.10

Kamatou GPP, Vermaak I, Viljoen AM, Lawrence BM (2013) Menthol: a simple monoterpene with remarkable biological properties. Phytochemistry 96:15-25. https://doi.org/ 10.1016/j.phytochem.2013.08.005

Kamel S, Ali N, Jahangir K et al (2008) Pharmaceutical significance of cellulose: a review. Express Polym Lett 2:758-778. https://doi.org/10.3144/expresspolymlett. 2008.90

Karapandzova M, Stefkov G, Trajkovska-Dokic E et al (2012) Antimicrobial activity of needle essential oil of pinus peuce griseb (Pinaceae) from Macedonian flora. Maced Pharm Bull 57:25-36

Kaur G, Athar M, Alam MS (2010) Eugenol precludes cutaneous chemical carcinogenesis in mouse by preventing oxidative stress and inflammation and by inducing apoptosis. Mol Carcinog 49:290-301. https://doi.org/10.1002/ mc.20601

Kędziora A, Speruda M, Krzyżewska E et al (2018) Similarities and differences between silver ions and silver in nanoforms as antibacterial agents. Int J Mol Sci 19:444. https://doi. org/10.3390/ijms19020444

Koneru A, Dharmalingam K, Anandalakshmi R (2020) Cellulose based nanocomposite hydrogel films consisting of sodium carboxymethylcellulose-grapefruit seed extract nanoparticles for potential wound healing applications. Int J Biol Macromol 148:833-842. https://doi.org/10.1016/j. ijbiomac.2020.01.018

Lautenschläger H (2009) (Poly)Saccharides in cosmetic products - From alginate to xanthan gum. Kosmet Prax 4:12-15

Lee KY, Jeong L, Kang YO et al (2009) Electrospinning of polysaccharides for regenerative medicine. Adv Drug Deliv Rev 61:1020-1032. https://doi.org/10.1016/j.addr. 2009.07.006

Leite AM, de Lima EO, de Souza EL et al (2007) Inhibitory effect of beta-pinene, alpha-pinene and eugenol on the growth of potential infectious endocarditis causing Grampositive bacteria. Rev Bras Ciências Farm 43:121-126. https://doi.org/10.1590/S1516-93322007000100015

Lin T-K, Zhong L, Santiago J (2017) Anti-Inflammatory and skin barrier repair effects of topical application of some plant oils. Int J Mol Sci 19:70. https://doi.org/10.3390/ ijms 19010070

Liu H, Chen M, Huang Z et al (2004) The influence of siliconcontaining acrylate as active diluent on the properties of UV-cured epoxydiacrylate films. Eur Polym J 40:609-613. https://doi.org/10.1016/j.eurpolymj.2003.10.018

Liu Z, Jiao Y, Wang Y et al (2008) Polysaccharides-based nanoparticles as drug delivery systems. Adv Drug Deliv Rev 60:1650-1662. https://doi.org/10.1016/j.addr.2008. 09.001

Maneewattanapinyo P, Banlunara W, Thammacharoen C et al (2011) An evaluation of acute toxicity of colloidal silver nanoparticles. J Vet Med Sci 73:1417-1423. https://doi. org/10.1292/jvms.11-0038 
Marchese A, Barbieri R, Coppo E, Orhan IE, Daglia M, Nabavi SF, Izadi M, Abdollahi M, Nabavi SM, Ajami M (2017) Antimicrobial activity of eugenol and essential oils containing eugenol: a mechanistic viewpoint. Crit Rev Microbiol 43(6):668-689

Midha K, Singh G, Nagpal M, Arora S (2017) Potential application of silver nanoparticles in medicine. Nanosci Nanotechnol-Asia 6:82-91. https://doi.org/10.2174/ 2210681205666150818230319

Mohamed R, Nurazzi NMN, Aisyah MIS, Fauzi FM (2017) Swelling and tensile properties of starch glycerol system with various crosslinking agents. Mater Scien Eng 223:012059. https://doi.org/10.1088/1757-899X/223/1/ 01205

Nesil T, Narmeen S, Bakhti-Suroosh A, Lynch WJ (2019) Effect of menthol on nicotine intake and relapse vulnerability in a rat model of concurrent intravenous menthol/nicotine selfadministration. Psychopharmacology 236:1219-1232. https://doi.org/10.1007/s00213-018-5128-9

Pavesi C, Banks LA, Hudaib T (2018) Antifungal and antibacterial activities of eugenol and non-polar extract of Syzygium aromaticum L. J Pharm Sci Res 10:337-339

Petkow L, Górkiewicz-Petkow A (2002) Nowoczesne opatrunki w leczeniu przewlekłych ran i owrzodzeń podudzi ze szczególnym uwzględnieniem opatrunków hydrokoloidowych. Przegląd Flebogiczny 10:101-105

Queen D, Orsted H, Sanada H, Sussman G (2004) A dressing history. Int Wound J 1:59-77. https://doi.org/10.1111/j. 1742-4801.2004.0009.x

Romeo FV, De Luca S, Piscopo A, Poiana M (2008) Antimicrobial effect of some essential oils. J Essent Oil Res 20:373-379. https://doi.org/10.1080/10412905.2008. 9700034

Roy N, Saha N, Kitano T, Saha P (2012) Biodegradation of PVP-CMC hydrogel film: a useful food packaging material. Carbohydr Polym 89:346-353. https://doi.org/10. 1016/j.carbpol.2012.03.008

Rufino AT, Ribeiro M, Judas F et al (2014) Anti-inflammatory and chondroprotective activity of (+)- $\alpha$-Pinene: structural and enantiomeric selectivity. J Nat Prod 77:264-269. https://doi.org/10.1021/np400828x

Sánchez-González L, Vargas M, González-Martínez C et al (2011) Use of essential oils in bioactive edible coatings: a review. Food Eng Rev 3:1-16. https://doi.org/10.1007/ s12393-010-9031-3

Semeniuc CA, Pop CR, Rotar AM (2017) Antibacterial activity and interactions of plant essential oil combinations against Gram-positive and Gram-negative bacteria. J Food Drug Anal 25(2):403-408

Shaaban HA, Mahmoud KF, Ibrahim MA, Ibrahim G (2014) Antimicrobial activity of edible methyl cellulose films enriched with essential oils against three common foodborne pathogens. World Appl Sci J 32:2092-2101. https://doi.org/10.5829/idosi.wasj.2014.32.10.86248

Singh R, Shitiz K, Singh A (2017) Chitin and chitosan: biopolymers for wound management. Int Wound $\mathrm{J}$ 14:1276-1289. https://doi.org/10.1111/iwj.12797

Smith AM, Moxon S, Morris GA (2016) Biopolymers as wound healing materials. Wound Healing Biomaterials. Elsevier, pp 261-287

South AB, Lyon LA (2010) Autonomic self-healing of hydrogel thin films. Angew Chemie Int Ed 49:767-771. https://doi. org/10.1002/anie.200906040

Spychaj T, Zdanowicz M, Kujawa J, Schmidt B (2013) Carboxymethyl starch with high degree of substitution: synthesis properties and application. Polimery 58:503-511. https://doi.org/10.14314/polimery.2013.503

Spychaj T, Wilpiszewska K, Zdanowicz M (2013a) Medium and high substituted carboxymethyl starch: synthesis, characterization and application. Starch - Stärke 65:22-33. https://doi.org/10.1002/star.201200159

Tey JN, Soutar AM, Priyadarshi A et al (2007) Ink and moisture sorption study in UV-curable polyurethane acrylate. J Appl Polym Sci 103:1985-1991. https://doi.org/10.1002/app. 25118

Wachal K, Stachowska E, Korpuścińska K et al (2018) Physical properties of hydrogel wound dressing and its use in lowlevel laser therapy (LLLT). Lasers Med Sci 33:1317-1325. https://doi.org/10.1007/s10103-018-2484-y

Wilpiszewska K, Antosik AK, Spychaj T (2015) Novel hydrophilic carboxymethyl starch/montmorillonite nanocomposite films. Carbohydr Polym 128:82-89. https://doi.org/ 10.1016/j.carbpol.2015.04.023

Wong TW, Ramli NA (2014) Carboxymethylcellulose film for bacterial wound infection control and healing. Carbohydr Polym 112:367-375. https://doi.org/10.1016/j.carbpol. 2014.06.002

Wu J, Sun X, Guo X et al (2017) Physicochemical properties, antimicrobial activity and oil release of fish gelatin films incorporated with cinnamon essential oil. Aquac Fish 2:185-192. https://doi.org/10.1016/j.aaf.2017.06.004

Zdanowicz M, Spychaj T (2014) Viscosity changes of aqueous carboxymethyl starch by partial crosslinking and montmorillonite addition. J Appl Polym Sci. https://doi.org/10. 1002/app.40793

Zeng W-C, He Q, Sun Q et al (2012) Antibacterial activity of water-soluble extract from pine needles of Cedrus deodara. Int J Food Microbiol 153:78-84. https://doi.org/10.1016/j. ijfoodmicro.2011.10.019

Publisher's Note Springer Nature remains neutral with regard to jurisdictional claims in published maps and institutional affiliations. 